\title{
A PROPOSED EXTENSION OF THE INSURABLE INTEREST REQUIREMENT FOR KEY MAN INSURANCE
}

TO PREVENT insurance from being used for improper purposes, ${ }^{1}$ courts permit insurance policies to be issued only to purchasers who have an insurable interest in the subject of the policy. 2 The holder of a life insurance policy has an insurable interest if he is so related to the person whose life is insured that the latter's death may result in a loss to him. ${ }^{3}$ The requisite relationship may be a pecuniary one. ${ }^{4}$ Thus, an employer has an insurable interest in the life of an employee whose death would mean financial loss to the employer. Although an insurable interest must exist at the time of issuance of a life insurance policy if the agreement is to be valid, generally no showing need be made that the interest continued until the date of death. ${ }^{7}$ Following this rule courts invariably hold that an employer's policy on his employee's life-so-called "key man" insurance-is not affected by the termination of employment and consequent disappearance of the employer's insurable interest in the subject of the policy. ${ }^{8}$ While in practice employers sometimes transfer such policies

1. See notes 20-24, 29-30 infra and accompanying text for discussion of improper uses of life insurance.

2. Werenzinski v. Prudential Ins. Co., 339 Pa. 83, 14 A.2d 279 (1940); VANCE, INSURANCE 156 (3d ed. 1951). An insurable interest is required for every type of insurance. 1 RICHARDS, INSURANCE 331 (5th ed. 1952).

3. While the loss must generally be a pecuniary one, VANCE, INSURANCE 183 (3d ed. 1951), in some jurisdictions an insurable interest may be based on other interests, as for example "affinity or consanguinity," ibid.; NEB. REv. Stat. \$\$ 44-103 (1952); N.Y. INSURANCE LaW \$ 146 .

4. See note 3 supra.

5. McMullen v. St. Lucie County Bank, $128 \mathrm{Fla} .745,175$ So. 721 (1937); In re Buse, 328 Pa. 211, 195 Atl. 9 (1937); MEHR \& OsLer, Modern Life Insurance 168, 427 (1949). An employer does not have an insurable interest in every employee's life. Turner v. Davidson, 188 Ga. 736, 4 S.E.2d 814 (1939) ; Newton v. Hicks' Adm'r, 282 Ky. 226, 138 S.W.2d 329 (1940). An insurable interest arises when "the success of the business is dependent on the continued life of the employee." Murray v. G. F. Higgins Co., $300 \mathrm{~Pa}$. 341, 346,150 Atl. 629, 630 (1930).

Employers also have insurable interests in the lives of their employees to the extent of possible liability in damages if the employees should be killed in the course of their employment. Geisler v. Mutual Benefit Health \& Acc. Ass'n, 163 Kan. 518, 183 P.2d 853 (1947), 32 MrNw. L. REv. 835 (1948).

6. See authorities cited note 2 supra.

7. Chapman v. Lipscomb-Ellis Co., 194 Ga. 640, 22 S.E.2d 393 (1942); Reilly v. Penn Mut. Life Ins. Co., 201 Iowa 555, 207 N.W. 583 (1925) ; VANCE, Insurance 185 (3d ed. 1951). For property insurance to be valid, however, an insured must have an insurable interest at the time of loss, because property coverage is considered to be indemnity insurance. Id. at $160,179$.

8. E.g., West End Sav. Bank v. Goodwin, 223 Ala. 185, 135 So. 161 (1931) (resignation); Alexander v. Griffith Brokerage Co., 228 Mo. App. 773, 73 S.W.2d 418 (1934) (discharge) ; Wurzburg v. New York Life Ins. Co., 140 Tenn. 59, 61, 203 S.W. 332, 333 (1918) (employee "forced" to leave the business). Texas reached a different result in 
to their employees when employment ends, ${ }^{9}$ an employer may maintain his policy in force and collect the proceeds at the death of his former employee. ${ }^{10}$ The reasons which courts advance for this result appear inadequate. This note will analyze the present rule and will suggest that an employee be permitted to assume a key man policy on his life once his employer's insurable interest terminates.

There are probably two reasons why courts developed a rule dispensing with the requirement of an insurable interest at the time of loss. Level premium life insurance originally had no cash surrender value. ${ }^{11}$ Therefore, if the termination of insurable interest were to preclude the receipt of death benefits, the purchaser of a policy would forfeit his investment of premiums paid less the cost of protection. ${ }^{12}$ But the primary explanation appears to be the desire by courts to protect the alienability of a life insurance policy in the hands of an insured who purchased it. ${ }^{13} \mathrm{~A}$ gift, sale or transfer as security of a life insurance policy would be impossible if the transferee were required to have an insurable interest at the time of loss. ${ }^{14}$ While these factors are seldom if ever mentioned in key man cases, they are the explicit bases for decisions on other types

Cheeves v. Anders, 87 Tex. 287, 28 S.W. 274 (1894) (partnership), but the decision has probably been changed by a recent Texas statute. TEx. REv. Crv. Stat. AnN. art. 3.49-1 (Vernon 1952) (Supp. 1955). See McCain v. Yost, 278 S.W.2d 398 (Tex. Civ. App. 1955) ; Swift, Insurable Interest Changes in Texas, 1953 INs. L.J. 666.

9. Herring, Key Man Insurance, 10 J. Aar. Soc'Y C.L.U. 57 (1955); Letters to the Yale Law Journal from the Metropolitan Life Insurance Company, Feb. 3, 1956, and the Security-Connecticut Life Insurance Company, March 2, 1956, on file in Yale Law Library.

10. Cases cited note 8 supra.

11. See Patterson, Insurance 307, 319, 320 (3d ed. 1955), commenting on Dalby v. The India and London Life-Assurance Co., 15 C.B. 365, 139 Eng. Rep. 465 (Ex. 1854) ; 1 Richarus, Insurance 373, 374 (5th ed. 1952).

"If the question [of extinguishment of insurable interest] were to be decided today, without regard to precedent, a just solution would be to allow the insured, whose interest has become extinguished, only the cash-surrender value (if any) of that date." PATTERSON, EsSENTMLLS OF INSURANCE LAW 140 (1935).

12. See note 11 supra. This seems to be the rationale of Ficke v. Prudential Ins. Co., $305 \mathrm{Ky} .171,202$ S.W.2d 429 (1947), where a divorced wife was permitted to collect the proceeds of a life insurance policy on her former husband's life. This case upset a line of Kentucky decisions in which it had been held that divorce terminates a wife's insurable interest and prevents recovery. See, e.g., Warren v. Spurlock's Adm'r, 292 Ky. 668, 167 S.W.2d S58 (1943). The court in the Ficke case was concerned over the disposition of the premiums the wife had paid, which exceeded the death benefits. A possible alternative to granting her complete recovery would have been to award her the policy's cash surrender value at the time of the divorce plus premiums paid since that time. The difference between that amount and the total premiums paid would be payment for the insurance protection she received during the marriage.

13. "The modern tendency in business seems to be in favor of making the transfer of life insurance policies as free as possible. . . " HuEBNER, LTFE INSURANCE 597 (1935); Swift, supra note 8 ; cases cited note 14 infra.

14. Cadore v. Cadore, 67 So. $2 d 635$ (Fla. 1953) (dictum; gift) ; Grigsby v. Russell, 222 U.S. 149 (1911) (sale) ; Gordon v. Ware Nat'l Bank, 132 Fed. 444 (8th Cir. 1904) (transfer as security). 
of life insurance which have furnished precedent for extension of the rule to the key man policy. ${ }^{15}$

Whatever the merit of these reasons with respect to other types of life insurance, they have no applicability to the validity of a policy after the termination of an employer's insurable interest in his employee's life. The termination of an insurable interest does not deprive an employer of his investment today. By surrendering his policy to the insurer the employer can recover its cash surrender value, which equals the premiums he has paid less the cost of the protection received. ${ }^{16}$ Similarly, the desire to protect the alienability of a life insurance policy in the hands of an insured has no relevance to key man insurance. Free transferability, especially for security purposes, is useful in encouraging the purchase of life insurance as an investment. ${ }^{17}$ However, employers buy insurance on their employees' lives for a limited purpose: to indemnify themselves against pecuniary losses suffered when their employees die. ${ }^{18}$ Inability to alienate will not deter employers from purchasing such insurance because alienation is inconsistent with their need for indemnity. ${ }^{10}$

15. E.g., Chapman v. Lipscomb-Ellis Co., 194 Ga. 640, 22 S.E.2d 393 (1942), citing Rylander v. Allen, 125 Ga. 206, 53 S.E. 1032 (1906) (assignment); Alexander v. Griffith Brokerage Co., 228 Mo. App. 773, 73 S.W.2d 418 (1934), citing Bowers v. Missouri Mut. Ass'n, 333 Mo. 492, 62 S.W.2d 1058 (1933) (divorce); Keckley v. Coshocton Glass Co., 86 Ohio 213, 99 N.E. 299 (1912), citing Grigsby v. Russell, 222 U.S. 149 (1911) (sale); In re Buse, $328 \mathrm{~Pa}$ 211, 195 Atl. 9 (1937), citing Wheeland v. Atwood, $192 \mathrm{~Pa} .237,43$ Atl. 946 (1899) (assignment).

16. See Alexander v. Griffith Brokerage Co., supra note 15, at 776, 73 S.W.2d at 420.

"In respect to this investment value the insured's claim is not unlike that of bank depositor or other holder of a chose in action." Patterson, Insurable Interest in Life, 1S Colum. L. Rev. 381, 383 (1918). See also Hujbrner, Life Insurance 277 (1935); Patterson, Essentials of Insurance Law 140 (1935), quoted note 11 supra.

17. Huebner, Life Insurance 622 (1935); Olson, Life Insurance Ozmership, 3 J. Am. Soc'x C.L.U. 17 (1948).

18. In discussing this type of insurance Chief Justice Taft said, "Life insurance in such a case is like that of fire and marine insurance, a contract of indemnity. . . . The benefit to be gained by death has no periodicity. It is a substitution of money value for something permanently lost either in a house, a ship, or a life." United States v. SuppleeBiddle Hardware Co., 265 U.S. 189, 195 (1924). (Emphasis added.) See Cheeves v. Anders, 87 Tex. 287, 28 S.W. 274 (1894); Herring, supra note 9; Kibrick, Selling Busitcss Life Insurance, 79 Trusts \& Estates 231 (1944); Mehr, Key Man Life Insurance and the Business Enterprise, 4 J. AM. Soc'y C.L.U. 131 (1950).

19. Moreover, if an employee became more valuable as his work continued, in theory an employer's need for insurance protection would increase. This contrasts with the theoretical decline in the need for insurance protection (as distinguished from the nced for life insurance generally) by a family man as his children approach maturity. Letter from Security-Connecticut Life Insurance Company to the Yale Lai' Journal, March 2, 1956, on file in Yale Law Library.

However, the usefulness of a key man policy as a credit source would not be eliminated. An employer could use a policy to obtain a loan up to the policy's cash surrender value from the insurer or from another financial institution. This compares with the credit value of any indemnity policy, such as a fire insurance agreement, where creditors secured by the policy are limited to the insured's interest at the time of loss. Sheridan v. Pacific States Fire Ins. Co., 107 Or. 285, 288, 212 Pac. 783, 784 (1923) (dictum); Flint Frozen Foods, Inc. v. Fireman's Insurance Co., 8 N.J. 606, 610, 86 A.2d 673, 674 (1952) (dictum); 
The considerations which underlie the requirement of an insurable interest at the inception of a policy are equally persuasive for requiring an employer to have an insurable interest at the time of loss. One function of the requirement of an insurable interest is to prevent gambling, which public policy has long condemned. ${ }^{20}$ Wagering on human lives is particularly disfavored. ${ }^{21}$ Although it is arguable that any insurance contract presents some aspects of gambling, ${ }^{22}$ insurance performs a socially desirable function as long as a beneficiary obtains no net gain on the occurrence of the event insured against, but is merely compensated for what would otherwise be a loss. ${ }^{23}$ However, an employer who continues a policy after employment has been concluded is doing no more than speculating in human life. He stands to suffer no pecuniary loss by the death of his former employee, and the hope for gain through premature death may well be his motive for continuing a policy. ${ }^{24}$ Such speculation, it is true, is not always condemned. Some courts have permitted a creditor to maintain a policy on his debtor's life despite extinguishment of the debt which gave rise to the creditor's insurable interest. ${ }^{25}$ In these cases the courts considered that only original gambling, not subsequent speculation, was objectionable. ${ }^{26}$ But other cases on this issue, which is highly analogous to the key man problem, have held that a life insurance policy can exist only collaterally

VANCE, INSURAnce 757, 761 n.20, (3d ed. 1951), and cases there cited; Patterson, Unsecutred Creditor's lousurance, 31 CoLuM. L. Rev. 212, 231, 233 (1931) (transfer of right to policy proceeds by "loss payable" clause). If an employer's insurable interest were terminated, his creditor could collect nothing except the cash surrender value.

20. Connecticut Mut. Life Ins. Co. v. Schaeffer, 94 U.S. 457 (1876); Bromley's Adm'r v. Washington Life Ins. Co., 122 Ky. 402, 92 S.W. 17 (1906); Elmore v. Life Ins. Co., 187 S.C. 504,198 S.E. 5 (1938).

21. Warnock v. Davis, 104 U.S. 775 (1881) ; Patterson, Essentials of Insurance LaW 132-34 (1935).

22. For a discussion of the distinction between gambling and insurance, see WiLLETr, The Ecanoanic Theory of Risk and Insurance 115-17 (1901).

23. KNIGHT, Risk, UnCERTAINTY AND PROFIT 247-52 (1921); WILLETT, op. cit. supra note 22 , at $115-17$.

24. Because the total premiums with interest to be paid for a life insurance policy on any given individual are calculated to exceed the death benefits, an employer can make a favorable investment only if the insured does not attain his life expectancy. Patterson, Instrable Interest in Life, 18 CoLuns. L. Rev. 381, 383 (1918). For an example of the amounts involved, see Lyman v. Jacobsen, 128 Ore. 567, 275 Pac. 612 (1929). The chance to treat death benefits as income tax free returns of capital makes the gamble more attractive. See Herring, sutpra note 9.

25. Appeal of Corson, $113 \mathrm{~Pa}$. 438, 6 Atl. 213 (1886) ; 1 Richards, Insurance 506511 (5th ed. 1952) ; Patterson, Insurable Interest in Life, 18 CoLuns. L. REv. 381, 415-16 (1918). On analogous reasoning other cases permit recovery by a creditor who received an assignment of a policy originally purchased by his debtor. E.g., Watson v. Massachusetts Mut. Life Ins. Co., 140 F.2d 673 (D.C. Cir. 1943). Nor does death and payment of the policy proceeds to the creditor discharge the debt. Id. at 676 (dictum); 1 RTCHARDs, INSURANCE 395,396 (5th ed. 1952).

26. E.g., Watson v. Massachusetts Mut. Life Ins. Co., supra note 25. Courts adopting this view reason that only professional gamblers are to be denied the opportunity to use life insurance as a vehicle for speculation and that the requirement of an insurable interest at inception is effective to prevent professional gamblers from obtaining life insurance. Patterson, 
to a debt. ${ }^{2 \pi}$ In this view recovery by a creditor-beneficiary is linited to the amount of his insurable interest at the time of death. ${ }^{28}$

A second reason generally given for requiring an insurable interest at the time a policy is issued is that such a requirement tends to eliminate any temptation by the purchaser to murder the insured in order to collect the policy proceeds. ${ }^{29}$ To the extent that this traditional policy factor is relevant in any context, it would seem relevant to key man insurance after employment ceases. When the employment relationship has been terminated, and the employer can suffer no loss on the death of the employee, allowing the employer to obtain

Insurable Interest in Life, 18 ColuMs. L. REv. 381, 391, 403 (1918). However, the requirement of an insurable interest at issuance has also been used to bar beneficiaries who are obviously not professional gamblers. Peoples First Nat'l Bank \& Trust Co. v. Christ, $361 \mathrm{~Pa} .423,65$ A.2d 393 (1949).

27. Tateum v. Ross, 150 Mass. 440, 23 N.E. 230 (1890) (alternative holding; recovery on policy would permit creditor to recover twice on his debt); Morrow v. National Life Ass'n, 184 Mo. App. 308, 168 S.W. 881 (1914) ; Strode v. Meyer Bros. Drug Co., 101 Mo. App. 627, 74 S.W. 379 (1903) ; Pittsburgh Underwriters v. Mutual Life Ins. Co, $149 \mathrm{~Pa}$. Super. 554, 27 A.2d 278 (1942); 1 Richards, Insurance 396 (5th ed. 1952). Other cases have reached the same result where the policy was assigned by the debtor to the creditor. Bosma v. Evans, 96 Colo. 504, 44 P.2d 511 (1935) (substitution of beneficiary who paid premiums held mere assignment) ; Merchants Bank v. Garrard, 158 Ga. 867, 124 S.E. 715 (1924) (assignment as change of beneficiary); Smith v. Coleman, 184 Va. 259. 35 S.E.2d 107 (1945). See Watson v. Massachusetts Mut. Life Ins. Co., 140 F.2d 673 (D.C. Cir. 1943), for a discussion of the similarity between assignment to and purchase by a creditor.

None of these decisions gives a satisfactory explanation for its result. The proper rationale would appear to be that for a creditor to be entitled to purchase insurance on his debtor's life, he must discharge the debt pro tanto on receipt of the death benefits. In turn the creditor has a claim against the debtor's estate on an unjust enrichment theory for premiums he has paid. This claim should not exceed the death benefits remaining after payment of the debt. Courts treat the debt and the claim for premiums as the total amount of insurable interest. The creditor is therefore not entitled to death benefits in excess of this amount. This surplus is considered a trust fund in the hands of the creditor for the benefit of the debtor's estate. Saville v. Lee, 43 Ga. App. 263, 158 S.E. 441 (1931); Tateum v. Ross, supra; Morrow v. National Life Ass'n, supra; Hayward v. Campbell, 174 Md. 540, 199 Atl. 530 (1938).

Courts often refer to a policy which a creditor buys on his debtor's life as security for the debt. But this is only partly correct. Security is property furnished by the debtor which is to be liquidated by the creditor on default. This is not the purpose of insurance which a creditor purchases on his debtor's life. Such insurance merely guarantees payment of a debt existing at the time of the debtor's death. However, the assignment of a policy by a debtor to his creditor may be a true security transfer, giving the creditor the right to liquidate the policy if there is a default. But if the debt is paid when due, the policy must be reassigned to the debtor. See, generally, Comment, The Assignment of Life Insurance as Collateral Security for Bank Loans, 58 Y ALE L.J. 743 (1949).

28. See note 27 supra.

29. Commonwealth Life Ins. Co. v. George, 248 Ala. 649, 652, 28 So. $2 d$ 910, 912 (1947); Cheeves v. Anders, 87 Tex. 287, 28 S.W. 274 (1894); 1 Richards, Insurance 372 (5th ed. 1952) ; Patterson, Insurable Interest in Life, 18 Colum. L. Rev. 381, 389 (1918); if. Griffin v. AfcCoach, 313 U.S. 498 (1941) (dictum). For criticism of the "reduce the incentive to murder" argument, see Grigsby v. Russell, 222 U.S. 149, 156 (1911) ; Patterson, sitpra at 389-90. 
the death benefits encourages murder as much as life insurance ever does. ${ }^{30}$ While it would be unreasonable to attribute the motives of gambling and murder to all employers who retain key man policies when employment ceases, there seems to be no other explanation but carelessness. ${ }^{31}$ And whatever weight is attributed to these factors, they should be decisive. After employment has terminated, life insurance serves no socially desirable function, so that any incidence of gambling or murder in this area is a net loss to society.

Abandonment of the present rule that no insurable interest is required at the time of death would necessitate an enlarged definition of "employment relationship." Since this relationship is the basis of the insurable interest, ${ }^{32}$ the termination of employment-even because of illness-would terminate insurable interest also. But in some cases it would be harsh to deny recovery to an employer if his employee left him because of illness, and death resulted from that illness. Yet if an employee had a heart attack, ceased working for that reason only, and died one year later, an employer would be ineligible for death benefits under a narrow definition of employment relationship. But he suffers a loss in this situation because at death he loses the expectation that the employee will return and render valuable services. In such a situation, despite expiration of the employment contract, the parties may intend that the relationship continue. ${ }^{33}$ It may be regarded as suspended only and should remain the basis of an insurable interest. In cases of this type courts could determine realistically and equitably whether there was a reasonable possibility that the employee would return to work, ${ }^{34}$ and thus whether the employment relationship had ceased in fact.

Recognition of the principle that an employer may not continue a policy in force would permit the benefits of life insurance to be made available to employees where they might otherwise not be obtainable. When an employer's insurable interest in a key man ceases, the policy could either be surrendered to the insurance company or transferred to the employee. From the standpoint of the employer, there would seldom if ever be any good reason for relinquishing such policies to the insurer. Similarly from the insurance company's point

30. McBride v. Clayton, 166 S.W.2d 125 (Tex. Comm. App. 1942), 21 Texas L. Rev. 648 (1943); Note, 9 Mo. L. Rev. 378 (1944).

31. Cf. Ryan v. Andrewski, 206 Okla. 199, 242 P.2d 448 (1952).

32. See notes 3-5 supra and accompanying text.

33. Even under a narrow definition of employment relationship courts consider an employer's interest to extend beyond his contract term. Patrerson, Essentials of InsurANCE LAW 150 (1935).

34. Factors to be considered might include the probable duration of the illness, the employee's age, the effect on the employer of the cessation of employment considering the age and ability of a replacement employee, if any, and the employer's training program.

It may be argued that an employee's illness should not be a factor in determining whether employment has ceased. In this view even an explicit termination of employment caused by illness would be disregarded. But this seems incorrect because the event insured against is death and not the occurrence of illness. Perhaps a type of key man insurance should be developed to protect the employer from loss due to termination of employment because of illness, resignation or any other reason, even including discharge. 
of view, it would be preferable to have such policies remain in effect. ${ }^{35}$ Often the insured employee would be glad to assume a policy upon payment of its cash surrender value to the owner-employer. An employee may not wish to continue the policy in every situation, but when he does, a policy would usually perform the main functions of life insurance: protecting the insured's dependents and providing a means of investment for the policy holder. ${ }^{36}$ For example, if an employee leaves work because of illness he may very much need a policy for family protection. Yet his health may preclude his obtaining other insurance. ${ }^{37}$ And on termination of employment an employee-insured in good health may establish a business of his own. If he is permitted to maintain a policy, he obtains its protection for his family at a cost lower than that required for the purchase of comparable new insurance and he has more funds to invest in his business. ${ }^{38}$

It would be desirable to have the insurance contract provide explicitly for transfer to the employee upon payment to the employer of the cash surrender value. State regulation could require a clause in key man insurance policies providing that on termination of employment the employer must surrender the policy to the company, which in turn must give the employee the opportunity to continue it in force. ${ }^{39}$ This would assure employees of an opportunity to maintain the insurance. ${ }^{40}$ Even in the absence of such a policy provision, courts should compel the employer to transfer the policy to the employee on payment of the cash surrender value. An employee's consent is required for the purchase of life insurance by his employer, ${ }^{41}$ and judges seeking a rationale for enforcing transfer could find an implied term in this agreement, if not in the employment contract. ${ }^{42}$ Under current law, cases may also arise where an employer has

35. Letters to the Yale Law Journal from the Aetna Life Insurance Company, Dec. 28, 1955, the Connecticut General Life Insurance Company, Jan. 5, 1956, and The Prudential Insurance Company of America, Jan. 13, 1956, on file in Yale Law Library.

36. Berman, Life Insurance: A Critical Examination 145 (1936); Huebnek, Life Insurance 25-43 (1935); Olson, Life Insurance Ozenership, 3 J. Adr. Soc'y C.L.U. 17 (1948).

37. See Huebner, Life Insurance 509, 570, 571 (1935) ; Memr \& Osler, Modern Life InSURANCE 254-57 (1949).

38. The importance of low cost insurance to businessmen is indicated by a recent announcement of General Motors Corporation. "Curtice [President of General Motors] announced the first large-scale group life insurance program for U.S. auto dealers. The program, to be financed jointly by the company and G.M. dealers, will call for a $\$ 1$ bilion fund, provide up to $\$ 100,000$ in low-cost life insurance (zuithout a physical cxamination) for any G.M. dealer under the age of 65." Time, Feb. 20, 1956, p. 83. (Emphasis added.)

39. For discussion of the authority of state insurance regulatory agencies, see Osborn v. Ozlin, 310 U.S. 53 (1940) ; HuEBNER, LIFE INSURANCE 549-61 (1935); VANCE, INSURANCE 36-51 (3d ed. 1951).

40. Employees would not be exposed to the risk that policies might be terminated without notification to them. If employers were to be liable in such situations for failure to inform employees of their transfer rights, employers would in effect become insurers, a result which is manifestly undesirable.

41. VANCE, INSURANCE 207-08 (3d ed. 1951).

42. Cf. Parev Products Co. v. I. Rokeach \& Sons, Inc., 124 F.2d 147, 149 (2d Cir. 
continued a policy until his employee's death, long after termination of employment. In such situations the employee's estate should be entitled to a share of the policy proceeds. ${ }^{43}$ If the insurable interest requirement is to be meaningful, the employer's recovery should be limited to the cash surrender value when employment terminated, plus premiums paid since that time. The balance of the death benefits if paid to the employer might be considered a trust fund for the decedent's estate. Where creditors have maintained life insurance on their debtors; courts use a similar trust device to restrict recovery to the amount of insurable interest at the time of death. ${ }^{44}$

$1941)$; Fenning v. American Type Founders, Inc., 33 N.J. Super. 167, 176, 109 A.2d 689, 693 (App. Div. 1954).

"In the more recent cases the courts are beginning to see and to admit that the finding of an 'implied term' or an 'implied condition' is frequently a pure construction by the court itself for the purpose of attaining a 'just' result under circumstances that the parties did not foresee and as to which they had no ideas and made no provision." 3 CoRBin, ConTRACTS 521 (1950). "The exact terms of the promise that is 'implied' must frequently be determined by what equity and morality appear to require after the parties have come into conflict." 1 id. at 38 . See also 3 id. $\$ 632 ; 5$ id. $\$ 1205$; Patterson, Constructive Conditions in Contracts, 42 Coluar. L. REv. 903 (1942). The equities of the situation all favor transferring the policy to the employee. The employer suffers no loss since he receives the policy's cash surrender value; insurance companies prefer to have the policies continue in force; opportunities for investment become available to the employee, and provision is made for his dependents. See notes 35-38 supra and accompanying text.

43. McBride v. Clayton, 166 S.W.2d 125 (Tex. Comm. App. 1942), and Cheeves v. Anders, 87 Tex. 287, 28 S.W. 274 (1S94) (partnership), reached this result. The rule of these cases has since been changed by statute, however. See note 8 supra.

44. See discussion in note 27 supra. 